\title{
The long-term effects of take-overs on the South African economy
}

\author{
N. Bhana \\ Graduate School of Business, University of Durban-Westville, Durban
}

\begin{abstract}
Acquiring companies prefer growth through acquisitions and mergers rather than growth by direct investment in manufacturing resources. A justification for the large number of take-overs is the belief that abnormal gains are to be obtained so. There is substantial empirical evidence showing this untrue. Take-overs contribute im mediate short-term gains, and are preferred to internal expansion where the benefits accrue over the long-term. Managers are usually evaluated on short-term performance criteria and therefore they have a bias for take-overs. Several investigators have studied the decline of the United States economy and the corresponding rise of Japan as industrial leader. The unrestrained take-over activity has been the chief reason for the decline of many industries in the United States. Acquiring companies have contributed to their own downfall by not investing sufficiently in up-to-date manufacturing resources. Takeovers lead to economic decline caused by lower productivity of acquired resources. South African companies are showing a strong preference for growth through take-overs. With the take-over process many local industries have come under the control of a few large conglomerates. South African acquiring companies could benefit by following the Japanese example of direct investments in technologically up-to-date manufacturing resources. More direct investment in manufacturing resources will lead to a more vigorous free-enterprise system and will raise the productivity of local industries. A more stringent Competition Act is necessary if South Africa is to avoid the harm to the economy caused by unrestrained take-over activity. S. Afr. J. Bus. Mgmt. 1984, 15: 229-231
\end{abstract}

Oomame-maatskappye verkies groei deur middel van oornames en samesmelting bo groei deur direkte belegging in vervaardigingshulpbronne. Die groot aantal oornames word geregverdig deur te glo dat abnormale winste so behaal kan word. Aansienlike empiriese bewyse bestaan egter daarteen. Oomames lewer onmiddellik korttermynwinste en word verkies bo interne uitbreiding wat winste oor 'n lang termyn ophoop. Bestuurders word gewoonlik op korttermyn. werkverrigtingkriteria beoordeel en daarom is hulle ten gunste van oomames. Verskeie navorsers het die afname in die V.S.A. se ekonomie en die ooreenstemmende opkoms van Japan as industriêle leier bestudeer. Die onbeheersde oomame-aktiwiteite was die hoof oorsaak vir die agteruitgang van baie nywerhede in die V.S.A. Oomame-maatskappye het bygedra tot hulle eie ondergang deur nie voldoende te belê in moderne vervaardigingshulpbronne nie. Oornames het gelei tot ekonomiese agteruitgang veroorsaak deur laer produktiwiteit van aangeskafde produksiemiddele. Suid-Afrikaanse maatskappye toon 'n sterk voorkeur vir groei deur oomames. Tydens die oorname-proses het baie plaaslike nywerhede onder die beheer van 'n paar groot konglomerate beland. Suid-Afrikaanse oornamemaatskappye kan baat vind by die Japanse voorbeeld naamlik direkte beleggings in moderne tegnologiese nywerheidshulpbronne. Meer direkte belegging in vervaardigingshulpbronne sal lei tot ' $n$ meer kragtige vryemarkstelsel en die produktiwiteit van plaaslike nywerhede sal toeneem. Strenger wetgewing ten opsigte van mededinging is nodig indien Suid-Afrika die skadelike invloede veroorsaak deur onbeheersde oomame-aktiwiteite op die landsekonomie wil vermy.

S.Afr. Tydskr. Bedryfi. 1984, 15: 229-231

\section{N. Bhana}

Graduate School of Business, University of Durban-Westville,

Private Bag X54001, Durban, 4000 Republic of South Africa

\section{Introduction}

The number of acquisitions and mergers continues to increase in the United States and countries in the Western World. The recession during the 1980-1982 period did not result in any decrease in acquisitions and mergers. In fact acquisitions and mergers actually increased during this slow-down period in the economies of the Western World. South Africa followed the trend in the United States by recording a substantial increase in take-over activity. How does one explain this phenomenon when the overwhelming evidence show that on average business take-overs are unsuccessful?

\section{The profitability of take-overs}

Several studies have shown the adverse effect of a policy of unrestrained acquisitions and mergers. A natural consequence of the process of acquisitions and mergers is economic concentration. Several researchers have observed that concentration of economic power leads to decreased profitability and productivity. Bellico (1981:51-64) has shown a positive relationship between increase in economic concentration and a decrease in productivity in the United States during the 1960's and 1970's. While there are several reasons for a decline in productivity, the declining level of investment in new plant and equipment plays a major role. Acquiring companies prefer growth through acquisitions and mergers rather than achieving growth through internal investment. Therefore, acquisitions and mergers contribute directly to the decrease in productivity and profitability. Edmunds (1981:507-519) has shown that the rate of earnings on assets declined with increasing company size for all industries in the United States during the period 1974-1978. This study suggests that smaller economic units will raise the profitability in the manufacturing industries. Furthermore, a reversal of the current conglomerate movement will create more efficient sized corporate structures.

There is substantial empirical evidence showing that acquiring companies do not make abnormal gains from acquisitions and mergers. Aivazian and Callen (1980:379-398) have developed a model which distributes the gains arising from take-overs. According to this model the total benefits are split evenly between the acquiring and acquired companies. However, for most take-overs the acquired company is much smaller than the acquiring company and therefore the target company captures the greater proportion of take-over benefits. Bradley, Desai \& Kim (1982) offered further evidence on the distribution of gains arising from acquisitions and mergers. This study has shown that in a multiple-bidder 
situation a far greater proportion of the take-over gains accrue to the target company shareholders whereas in a singlebidder situation the gains are shared in approximately equal proportions.

The rational expectations of market participants has been widely used to explain the pricing mechanism in the free enterprise system. Rational expectations are expressions of the forward thinking of the participants based on information available to them and the use of such knowledge in investment decisions. Different participants in the market are expected to hold divergent expectations depending on the information they possess. It is the function of the market to co-ordinate the divergent expectations of the market participants. Lachmann (1982:9-13) has explained the important role of rational expectations in making the markets efficient.

Grossman \& Hart (1981:253 - 270) have shown that as long as shareholders have rational expectations about the take-over process the acquiring company is unlikely to make abnormal gains. It was observed that shareholders with rational expectations will realize the fact that the firm is under-valued on the market. Consequently they will revise upwards their valuation of the take-over bid. The acquiring company will have to offer sufficient premium that will reflect this revised valuation of the target firm's shares.

Dodd (1980:105 - 137) has provided evidence on the stockmarket reaction to the announcement and subsequent acceptance or rejection of the take-over proposals. This study has shown that there is a positive market reaction to the approval and completion of a take-over bid and a negative reaction to a cancelled proposal. In the case of the cancelled takeover bid the earlier positive reaction to the initial announcement is not eliminated by the market pricing mechanism.

Bradley, et al., 1982 provided evidence showing that the rationale for take-overs is the discovery by the acquiring company of undervalued and underutilized assets owned by the acquired company. Furthermore, this new information becomes public knowledge with the announcement of the takeover offer. Therefore, the shareholders of the acquired company will experience an increase in wealth as a result of the take-over offer regardless of the outcome of the bid. The price of the acquired company rises to reflect all the gains expected from acquiring it. Perfect competition in the market for corporate control leads to all the gains from the take-over accruing to the acquired companies' shareholders.

Brozen (1982) has provided evidence regarding the expectations of take-overs by the acquired-company shareholders and the impact thereof on the pre-bid market prices. It was observed that the pre-bid market price of the acquired company rises irrespective whether the take-over offer was expected or not. Furthermore, the premium above the pre-bid market price of the acquired company enables the acquiring company to earn a normal return on the investment.

\section{The rationale for take-overs}

There is a need to explain the growing popularity of takeovers despite clear evidence showing that this form of investment is not superior to the alternative of growth by internal expansion. Hayes \& Abernathy (1980:67-77) have already observed that corporate managers are unduly concerned with short-term benefits. Managers are usually evaluated on the basis of short-term yardstick such as the quarterly or annual R.O.I. Take-overs are preferred to internal expansion because acquisitions contribute immediate short-term gains. Therefore, acquiring companies prefer the lower but immediate gains from take-overs to the larger long-term gains from internal expansion.

An undue reliance on short-term benefits from take-overs result in overlooking many opportunities which are crucial in providing technical competence in the long-term. Reich (1983) has blamed unrestrained take-over activity as the chief reason for the uncompetitiveness of many industries in the United States. It can be argued that vast resources are tied up in take-overs at the expense of direct investment in manufacturing resources. An emphasis on short-term benefits ultimately leads to economic decline caused by the lower productivity of take-overs.

By contrast the strategic importance of acquisitions is not appreciated in Japan. Abbegglen (1983:16-20) has observed that few Japanese companies are involved in take-overs. Japanese managers are usually not evaluated on the basis of short-term performance such as quarterly results. Japanese managers are therefore influenced to make direct investments in manufacturing resources. The wisdom of this approach is that Japanese companies in the long-term have the most sophisticated plants and machinery. Japanese companies therefore have a competitive edge over their United States counterparts who prefer to grow by take-overs.

\section{Take-overs in South Africa}

South African companies are strongly influenced by management practice in the United States. South African acquiring companies also show a preference for growth through takeovers. There have been no detailed studies on the relative profitability of acquiring companies and those companies achieving growth through internal investment in the South African economy. The conglomerate companies are predominant in South African take-overs. Andrews (1979) has shown that the South African conglomerates have outperformed non-conglomerates in terms of growth and return on investment. A study by Mackintosch \& Bissotto (1981: 99-102) revealed that the returns of South African conglomerates are significantly higher than the average for the entire market.

The superior profitability of the South African conglomerates can be explained by the strategic nature of their takeovers. These conglomerates have concentrated on those takeovers giving them a monopolistic/oligopolistic control over the industries concerned. Therefore, the higher profits of the conglomerates are due mainly to their control over the market in specific industries. However, there is no empirical evidence on the profitability of take-overs where no control over the market is acquired. Nevertheless, the evidence on the profitability of such take-overs in the United States and other advanced economies indicate that acquiring companies are not expected to make abnormal gains from acquisitions and mergers.

The high level of take-overs in South Africa will have widespread repercussions for the local economy. The technological obsolescence and lower productivity accompanying take-overs is of particular importance to a developing country such as South Africa. The productivity of South African industry is notoriously low in relation to our main trading partners in the Western World. It is therefore important that more emphasis be placed on growth by direct investment in technologically up-to-date manufacturing processes. This approach will provide increased employment opportunities and will also raise the productivity of local industries.

The recent change in control of the South African 
Breweries group (SAB) once again exposed the dangers of the take-over process to the free enterprise system in South Africa. The SAB group itself has a monopolistic/oligopolistic control over several industries in which it operates. SAB is now controlled by the Anglo American Corporation (AAC). The AAC and its subsidiaries constitute the largest group of all companies listed on the Johannesburg Stock Exchange (JSE). It is extremely unlikely that the companies in the SAB group will encounter new competitors in those industries where they have gained market control. The concentration in the food industry has been created by take-overs consummated by the largest conglomerates in South Africa. New entrants into the food industry are unlikely as this would entail a confrontation with companies having the resource backing of the largest conglomerates in South Africa. As the takeover process continue more and more local industries will be controlled by a few large conglomerates. Based on the United States experience the take-over process will have the long-term effect of lowering productivity and decreasing the competitiveness of local industries.

The large number of take-overs in countries such as the United States and the United Kingdom has prompted the regulatory authorities in these countries to introduce legislation controlling business combinations. In South Africa there has also been a sharp increase in take-over activity in recent years; but legislation has not kept pace with the rapidly changing structure of business. The Maintenance and Promotion of Competition Act of 1979 has provided the machinery under which take-overs are to be investigated. Prior to the passing of this Act there was no legislation controlling take-overs in South Africa. The Competition Board has powers to investigate take-overs and make recommendations to the Minister of Economic Affairs to terminate those takeovers which are not in the public interest.

There have been several opinions questioning the effectiveness of the Competition Act. Critics of the Competition Board have referred to it as a 'toothless watchdog'. TregannaPiggott (1980:62-85) is of the opinion that the public-interest concept, which is the basis for regulating take-overs, has been vaguely defined and this has complicated the task of enforcing take-over legislation. A further deficiency of the Competition Act is that the Competition Board's investigations into take-overs had to be retrospective. However, a recent amendment to Section 8 of the Competiton Act now enables the Board to prevent the consummation of a take-over which is considered to be against the public interest. Despite the amendments to the Act, South Africa still lacks effective legislation to curb take-overs. A more stringent Competition Act is necessary if South Africa is to avoid the long-term harm to the economy caused by excessive take-over activity.

\section{Conclusion}

No conclusive evidence on the superior profitability of takeovers has been found. Nevertheless, corporate assets are increasingly being utilized to pursue take-over activity. Control over the markets and immediate short-term gains are the prime motives for the spate of take-overs now occurring in the United States and countries in the Western World. South African acquiring companies can benefit by studying the current state of industries in the United States and Japan. Japan has made inroads into the markets of the United States and other Western Countries. The trade advantages of Japan has been achieved largely owing to following a policy of direct investment in manufacturing resources. Those countries such as the United States who have relied on take-overs for growth are paying the price of lower productivity caused by technological obsolescence.

It is submitted that the South African economy will be better served if the conglomerates employed their resources towards internal investment in manufacturing activities. A more vigorous free-enterprise system and the raising of productivity is crucial for the competitiveness of the South African economy. Furthermore, direct investment in manufacturing resources creates economic growth which is vitally necessary to raise the standard of living in South Africa. It is recommended that South African acquiring companies be more circumspect in their take-over activity. The long-term technological benefits of direct investment must be given consideration when take-overs are contemplated. Appropriate amendments to the Competition Act are necessary to enable a more effective control over take-over activity in South Africa.

\section{References}

Abbegglen, J.C. 1983. Can Japanese Companies be Acquired? Mergers Acquis, vol.17, 16-20.

Aivazian, V.A. \& Callen, J.L. 1980. Corporate Leverage And Growth J. Fïnanc. Econ., vol.8, 379-398.

Andrews, G.S. 1979. Strategy and Financial Performance of South African Industrial Companies, Unpublished Doctoral disseration. Graduate School of Business, University of Cape Town.

Bellico, R. 1981. An Indictment of Monopoly Power. Econ. Forum, vol.12, 51-64.

Bradley, M.,Desai, A. \& Kim, E.H. 1982. Specialized Resources and Competition in the Market for Corporate Control. Unpublished Manuscript, University of Michigan, 34p.

Brozen, Y. 1982. Mergers in Perspective. Washington, D.C. American Enterprise Institute. $88 \mathrm{p}$.

Dodd, P. 1980. Merger Proposals, Management discretion and Stockholder Wealth. J. Financ. Econ., vol.8, 105-137.

Edmunds, S.W. 1981. Organizational size and efficiency in the United States. Antitrust Bull., vol.26, 507-519.

Grossman, S.J. \& Hart, O.D. 1981. The Allocation Role of Take-over Bids. J. Finance, vol.36, 253-270.

Hayes, R.H. \& Abernathy, W.J. 1980. Managing our way to economic decline. Harv. Bus. Rev., 67-77.

Lachmann. L.M. 1982. Why expectations matter. Investm. Anal. J., $9-13$.

Mackintosch, R.G.J. \& Bisotto, F.E. 1981. South African Conglomerates: A Qualitative analysis. S. Afr. J. Bus. Mgmt., vol.12, 99-102.

Reich, R.B. 1983. The Next American Frontier. New York: Times Book, 324p.

Treganna-Piggot, JV. 1980. Competition Policy in South Africa. Volkskas Finance Trade Rev., vol.14, 62-85. 